\title{
Geoelectrical Characterization of Aquifer Precincts in Parts of Lapai, North Central Nigeria
}

\author{
${ }^{* 1}$ TSEPAV MT; $*{ }^{2}$ SI. IBRAHIM, ${ }^{1}$ FA. BAYEGUN \\ ${ }^{1}$ Department of Physics, Ibrahim Badamasi Babangida University, Lapai, Nigeria. \\ ${ }^{2}$ Department of Geography, Ibrahim Badamasi Babangida University, Lapai, Nigeria. \\ * Corresponding author: tsematoo@yahoo.com, 08173967772
}

KEYWORDS: Conductance, transmissivity, protective capacity, aquifer characterisation.

\begin{abstract}
Some geoelectric characteristics of aquifer in parts of Lapai, Central Nigeria were evaluated using Wenner vertical electrical sounding (VES) method. Fifteen (15) VES points were occupied using G41 Geotron Resistivity meter with electrode spacing varying from $10 \mathrm{~m}$ to $150 \mathrm{~m}$ while a global positioning system (GPS) tracking device was used to locate the VES points. The 1xD Interprex interpretation software was used for the data interpretation which revealed four layers comprising the top lateritic soil, silty /clayey, weathered basement and fresh basement rocks. The resistivity of these layers varied from $4.54 \Omega \mathrm{m}$ to $27987.60 \Omega \mathrm{m}$ while the depth varied from $0.440 \mathrm{~m}$ to $1079.5 \mathrm{~m}$. Longitudinal conductance and transverse resistance calculated from the layers' thicknesses and resistivities varied from 0.00039 Siemens to 2.05 Siemens and $3.96 \times 10^{6} \Omega \mathrm{m}^{2}$ to $3.34 \times 10^{7} \Omega \mathrm{m}^{2}$ respectively. The aquifer overburden protection capacity in VES 2, 5, 6,9,10 and 11 were relatively low which means the aquifer in these locations are susceptible to contaminants while in VES 15 the protective capacity is higher indicating that the aquifer is protected. Generally, all the locations could be exploited for groundwater at relatively reasonable depths. However, a greater part of the study area has low protective capacity (<1.0Siemens). The consequence of this revelation is that the area is generally unprotected as it allows for infiltration and subsequent contamination of the groundwater and hence good groundwater quality cannot be guaranteed in the area. (C) JASEM
\end{abstract}

http://dx.doi.org/10.4314/jasem.v19i2.17

\section{INTRODUCTION}

The electrical resistivity technique involves the measurement of the apparent resistivity of soils and rocks as a function of depth or position. The method of geophysical exploration happens to be the most applied method in groundwater exploration in areas where good electrical resistivity contrast exists between the water bearing formations and the underlying rocks (Nejad, 2009); and for reconnaissance search for minerals of economic importance. The method has been recognized to be more suitable for hydrogeological survey of sedimentary basin (Kelly and Stanislav, 1993); for the determination of depth, thickness and boundary of an aquifer (Omosuyi et al., 2007, Ismail, 2005); in determination of groundwater potential (Oseji et al., 2005); exploration of geothermal reservoirs (El-Qady, 2006); estimation of hydraulic conductivity of aquifer (Khalil and Monterio, 2009; Yadav, 1995); aquifer characterization (Mbonu et al., 1991); mapping of groundwater contaminant leachate plumes, contaminant source, migration paths, and depth (Griffiths and Barkers, 1993); and delineation of basement structures of the south central Bida Basin (Idornigie and Olorunfemi, 1992) among others.

Groundwater is a renewable resource and an essential commodity to mankind. When rain falls, some of the water flows on the earth surface and collect into streams while some sinks into the ground due to the effect of gravity, passing between soil particles and gravel or rock until it reaches the aquifer. The rate at which groundwater flows depends on the size of the spaces in the soils or how well the spaces are connected. As water percolates from the surface through different layers into the aquifer, there is the possibility of contaminants being carried along and hence the need for an understanding of the aquifer formation and characteristics for the purpose of ascertaining whether or not the aquifer is prone to contamination. Furthermore, the increase in the population of Lapai Town leading to an increased demand for water meant for domestic and agricultural purposes such as irrigation has become a serious concern over the years. Maintaining the existing water supplies has become difficult especially during the dry

*Corresponding author: Email: tsematoo@yahoo.com, 
seasons with possible solutions sought in groundwater exploration and exploitation as a suitable alternative. The resistivity methods, especially the Vertical Electric Sounding (VES) have been used successfully for investigating groundwater quality in different lithological settings. The method is well recognized as an effective, quick and economic means of obtaining details of the electrical characteristics of the subsurface at any location. Aside, the instrumentation is simple, field logistics are easy and the analysis of data is straight forward compared to other methods (Zohdy et al., 1974; Ekine and Osobonye, 1996; Sikander et al., 2010). The method was therefore applied to address these concerns.

\section{MATERIALS AND METHODS}

Location of Study Area: The study area is situated in Agwan Gwari layout along Gulu-Suleja road, Lapai. It is located between latitude $9^{\circ} 03^{\prime} 20^{\prime \prime} \mathrm{N}, 9^{\circ} 3^{\prime} 020^{\prime \prime} \mathrm{N}$ and $9^{\circ} 02^{\prime} 40$ "N and longitude $6^{\circ} 35^{\prime} 20^{\prime \prime} \mathrm{E}, 6^{\circ} 35^{\prime} 40^{\prime \prime} \mathrm{E}, 6$ '36'0”'E, $6^{\circ} 36^{\prime} 20^{\prime \prime} \mathrm{E}$ and $6^{\circ} 36^{\prime} 40^{\prime \prime} \mathrm{E}$. The area has an undulating topography that is covered with vegetation, shrubs, trees and grasses. It has fine grain texture of sand; clayey-sand, laterite and pebbles of granites with few visible exposures.

The area belongs to the basement complex of Nigeria as can be seen from the granitic intrusions that form a suite of batholiths which is composed mainly of gneisses and schist. The Basement Complex rocks of Nigeria comprise the Migmatite-Gneiss Complex, the Schist Belts and the Older Granites. It is made up of igneous and metamorphic rocks mainly of the Precambrian age that covers about $50 \%$ of Nigeria. (Obaje et al., 2006). Igneous and metamorphic rocks in western Nigeria are separated from the northern area by continuous outcrops of sedimentary rocks in the Mid-Niger and the Sokoto Basins. This area of Basement Complex rocks is lower on average than the northern one and elevations in these areas are generally below 500m (Obaje et al., 2006)

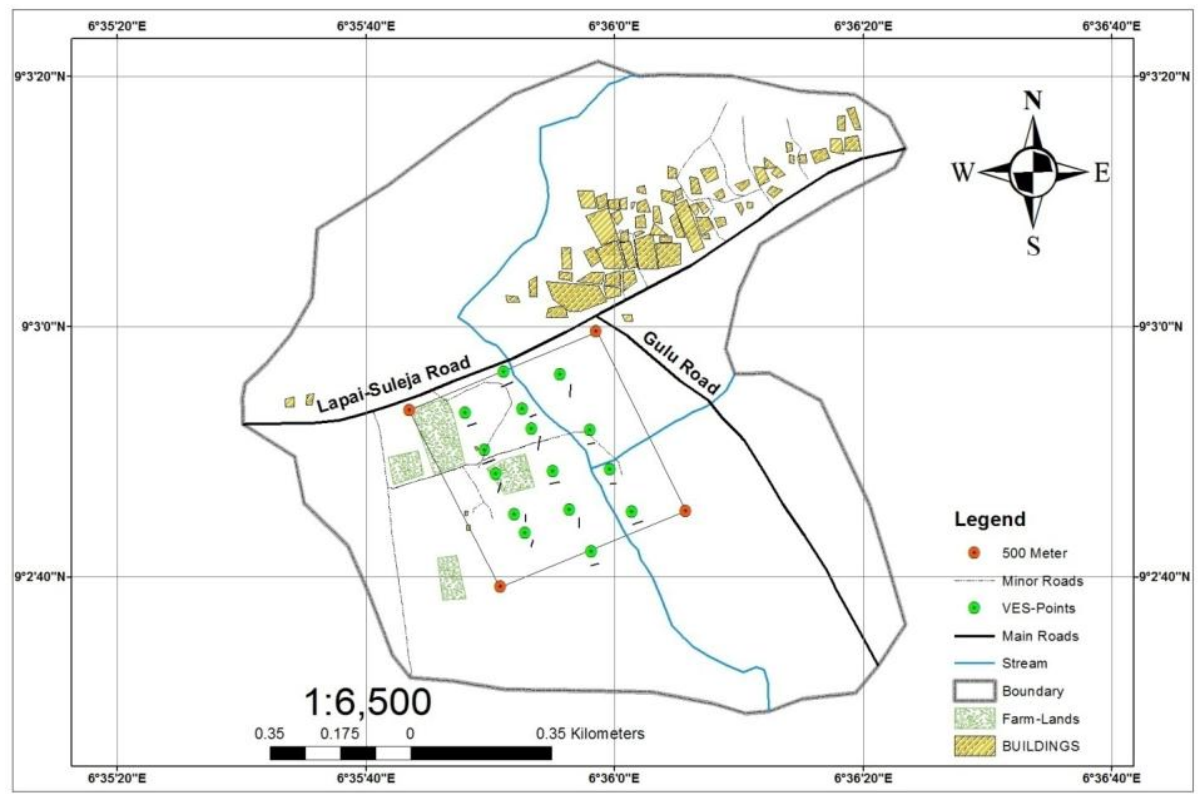

Fig 1.0: The Map of the Study Area

The physical principle underlying the electrical resistivity method is Ohm's law where an electric current, when introduced into the ground by means of two current electrodes sets up a stationary current field and because of the ohmic potential drop, an electrical potential field is also created. This field gets distorted in the neighbourhood of a subsurface zone of anomalous conductive body and the aim is to search for such anomalous zones in the electrical field. The assumption made here is that the current flow in the potential measuring circuit is negligible compared with the current flow in the ground, so that the ${ }^{* 1}$ TSEPAV MT; * ${ }^{2}$ SI. IBRAHIM, ${ }^{1}$ FA. BAYEGUN potential electrodes themselves will have no disturbing effects on the electrical field (Grant, and West, 1965).

The most common way of carrying out such measurements involves sending into the earth, a direct current (or very - low- frequency alternating current) through non-polarisable electrode pairs and measuring the potential drop associated with the current (Vingoe, 1972). The electrodes are inserted a few centimetres into the ground to make a proper electrical contact. Current is passed into the earth through $\mathrm{C}_{1}$ and received at $C_{2}$. The potential generated in the earth as 
a result of this current is measured between the potential electrodes $\mathrm{P}_{1}$ and $\mathrm{P}_{2}$ as shown in Figure2.

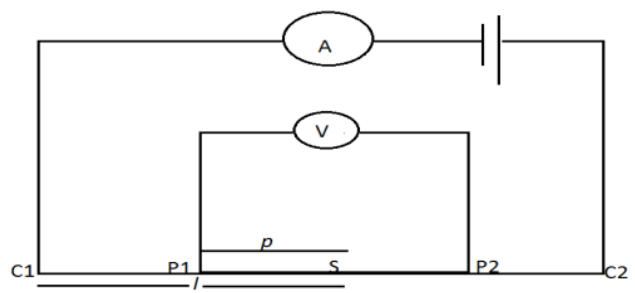

Fig 2: Electrode configuration

In Wenner Vertical Electrical Sounding, the four electrodes are collinear and the separations between adjacent electrodes arrangement is increased symmetrically about the sounding point. If $a$ is the electrode separation, then the apparent resistivity is given by:

$\rho_{a}=2 \pi a \frac{V}{I}$

In the Schlumberger Array, the current electrodes are placed much further apart than the potential electrodes and spread out symmetrically about the sounding point. If $\mathrm{S}$ is mid-point and $\mathrm{P}_{1}, \mathrm{P}_{2}$ are symmetrical about $S$ so that the distance $\mathrm{P}_{1} \mathrm{P}_{2}$ is $2 \rho$ and $\mathrm{C}_{1} \mathrm{~S}=\mathrm{C}_{2} \mathrm{~S}=$ $\mathrm{L}$ as shown in Figure 2 then,

$\rho_{a}=\frac{2 \pi \Delta U}{I}\left(\frac{1}{L}-\rho-\frac{1}{L}+\rho-\frac{1}{L}+\rho+\frac{1}{L}-\rho\right)^{-1}$

$\rho_{\mathrm{a}}=\frac{2 \pi \Delta \mathrm{U}}{\mathrm{I}}\left(\frac{4 \rho}{\mathrm{L}_{2}-\rho_{2}}\right)^{-1} \quad$ (3) For $\mathrm{L} \gg \rho, \rho_{\mathrm{a}}=\left(\frac{\pi \rho^{2}}{2 \mathrm{I}}\right) \frac{\Delta \mathrm{U}}{\mathrm{L}}$

(4) where: $\frac{\pi \rho^{2}}{2 I}=$ Array constant

Aquifer Protectivity and Transmissivity: The geoelectric parameters are of two orders. The first order are thickness $(h)$ and resistivity $(\rho)$ while the second order also known as Dar Zarrouk parameters which include transverse resistance (R) and longitudinal conductance (S) and are obtained from the first order geoelectric parameters and could be used as the basis for the evaluation of aquifer characteristics.

The longitudinal conductance $(S)$ is given by Nwankwo and Ehirim (2010) as the sum of all the thickness/resistivity ratios of $n-1$ layers which overlie a semi-infinite substratum of resistivity $\rho_{\mathrm{n}}$. The Dar-Zarouk parameter of longitudinal (S) is given as:

$\mathrm{S}_{\mathrm{i}}=\sum_{i=1}^{n} \frac{h_{i}}{\rho_{i}}$ (siemens) (5) where, $\rho_{i}=$ layer resistivity of the ith layer. $h_{i}=$ thickness of the ith layer.

For clean saturated aquifers whose natural fluid characteristics have no appreciable impact on the general ground water quality by surface contaminants, the hydraulic conductivity is proportional to the resistivity of the aquifer (Kelly, 1977; Mbonu et al., 1991) implying that in the absence of a pumping test data, the aquifer hydraulic conductivity $(\mathrm{K})$ can be approximated to the true resistivity of the aquifer derived from geoelectric investigation. Therefore,

$T=k h=\rho h$

The longitudinal conductance gives a measure of the impermeability of a confining clay layer which has low hydraulic conductivity and low resistivity. The protective capacity $\left(P_{c}\right)$ of the overburden layers is proportional to its longitudinal conductance.

When the longitudinal conductance value is greater than 0.7 mhos, the layers are adjudged zones of good protective capacity. The portion where the conductance value ranges between 0.2 and 0.69 mhos is classified as zones of moderately protective capacity. The zones which have conductance value ranging from 0.1 and 0.19 mhos are classified as zones of weak protective capacity and where it is less than 0.1 mhos are considered as poor aquifer protective capacity (Oladapo and Akintorinwa, 2007).

Aquifer transmissivity (T) is directly proportional to the resistivity (Kelly, 1977). The product of the resistivity and its thickness is known as the transverse resistance (R) and is numerically equal to the transmissivity, T. Transverse resistance $(\mathrm{R})$ is obtained from the expression:

$T_{i}=\sum_{i=1}^{n} \rho_{i} \cdot h_{i}\left(\mathrm{ohm} . \mathrm{m}^{2}\right) \quad$ (7) where $p_{i}$ is the layer resistivity and $h_{i}$ is the thickness of the ith layer.

The transverse resistance and hence the transmissivity of the aquiferous zones vary from $1.34 \times 10^{4}$ to $1.64 \times 10^{5} \Omega \mathrm{m}^{2}$. If the transverse resistance values are $>400 \Omega \mathrm{m}^{2}$ and correspond to zones where the thickness and resistivitiesof the aquifer are large, the aquifer materials are highly permeable to fluid movement within the aquifer, which may possibly enhance the migration and circulation of contaminants in the groundwater aquifer system ( Nwankwo and Ehirim, 2010).

Experimental Procedure: Wenner vertical electrical sounding was employed in data collection because of its high resolution abilities. In this configuration, the spacing for both the potential and current electrodes was expanded in steps of 10, 15, 20, 30, 45, 70, 100 and $150 \mathrm{~m}$ on each profile. The process was repeated until a total of fifteen sounding points were obtained by traversing across the stream in the area until the area under consideration was duly covered.

\section{RESULTS AND DISCUSSION}

The data obtained from the aforementioned procedure is shown in Table 1. These data was plotted against 
half electrode separation on a logarithmic scale and sounding interpretation software which provides an interpreted quantitatively using the Interpex $1 \mathrm{x} D$

Table 1:-Summary of Vertical Electrical Sounding (VES) data

\begin{tabular}{|c|c|c|c|c|c|c|c|c|c|c|c|c|c|c|c|c|}
\hline \multirow[t]{3}{*}{$\mathbf{S} / \mathbf{N}$} & \multirow{3}{*}{$\begin{array}{l}\mathbf{a} \\
(\mathbf{m})\end{array}$} & \multicolumn{15}{|c|}{ RESISTIVITY(Ohm-m) } \\
\hline & & VES & VES & VES & VES & VES & VES & VES & VES & VES & VES & VES & VES & VES & VES & VES \\
\hline & & 1 & 2 & 3 & 4 & 5 & 6 & 7 & 8 & 9 & 10 & 11 & 12 & 13 & 14 & 15 \\
\hline 1 & 10 & 60.88 & 59.50 & 163.68 & 110.39 & 33.36 & 91.70 & 229.28 & 122.98 & 112.12 & 96.52 & 35.84 & 34.06 & 39.04 & 36.07 & 63.54 \\
\hline 2 & 15 & 69.10 & 75.75 & 123.83 & 159.44 & 51.00 & 120.34 & 162.82 & 186.90 & 142.14 & 57.52 & 42.88 & 45.66 & 64.22 & 52.21 & 83.26 \\
\hline 3 & 20 & 65.48 & 99.45 & 151.42 & 182.98 & 78.94 & 149.56 & 191.66 & 243.32 & 161.60 & 83.30 & 46.18 & 46.22 & 63.32 & 69.33 & 101.22 \\
\hline 4 & 30 & 117.94 & 159.25 & 202.34 & 279.18 & 107.28 & 174.56 & 257.30 & 294.66 & 173.36 & 122.10 & 86.68 & 71.74 & 116.06 & 81.06 & 131.88 \\
\hline 5 & 45 & 190.60 & 220.53 & 264.05 & 361.62 & 165.96 & 258.76 & 292.22 & 300.26 & 208.22 & 157.56 & 119.56 & 106.66 & 182.92 & 125.29 & 753.46 \\
\hline 6 & 70 & 377.14 & 327.91 & 428.65 & 334.92 & 265.18 & 436.30 & 296.60 & 359.18 & 154.36 & 229.84 & 194.12 & 153.28 & 281.76 & 196.98 & 247.32 \\
\hline 7 & 100 & & & & & & & & & & & & & & & 306.64 \\
\hline 8 & 150 & & & & & & & & & & & & & & & 367.80 \\
\hline
\end{tabular}
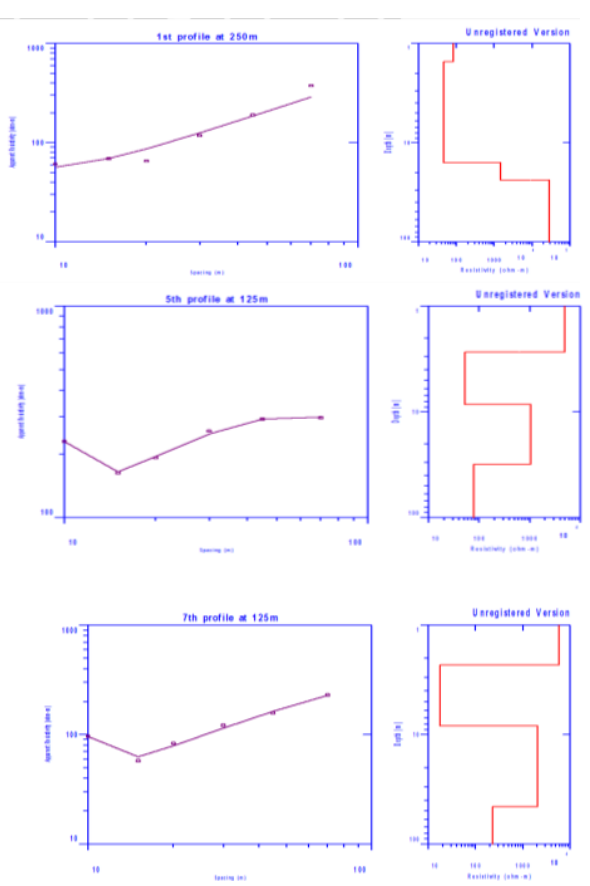
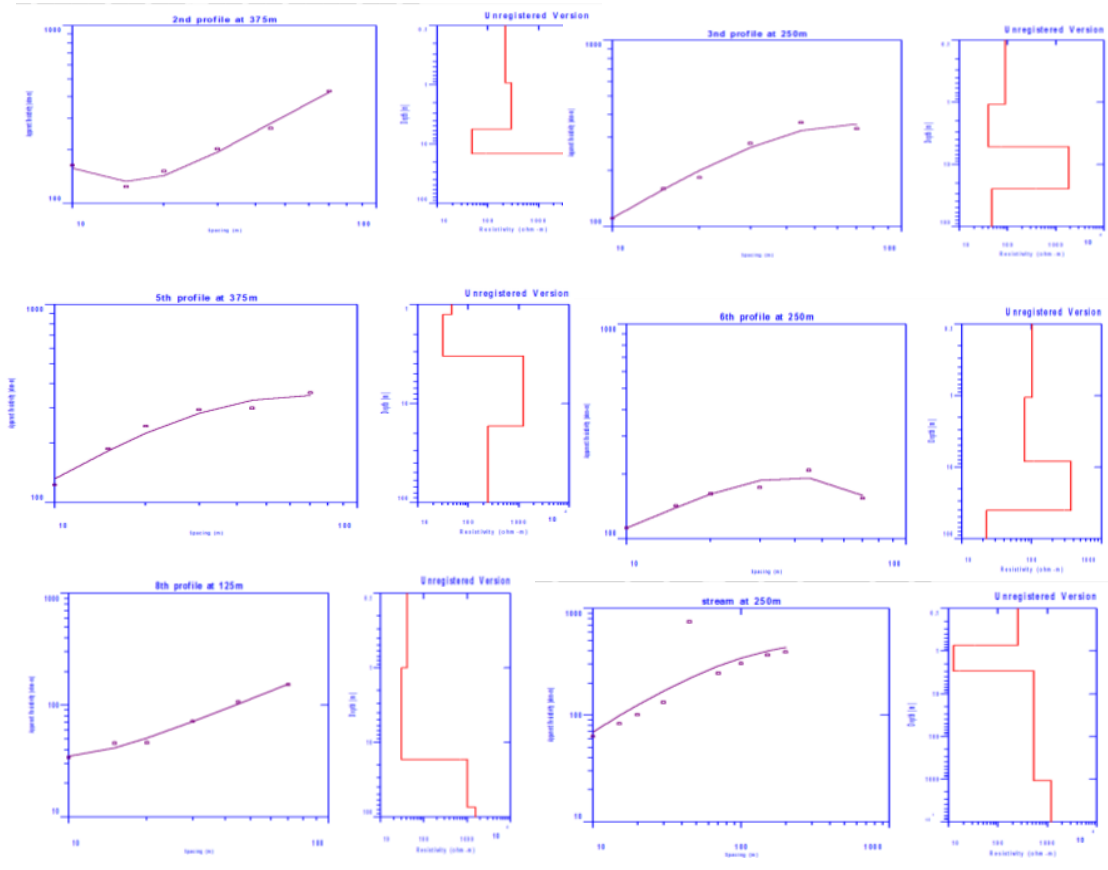

Fig 3: Resistivity models for selected

automatic means of analyzing and determining models. The results were subjected to iteration processes of the software to obtain the layers' true resistivities and thicknesses. Some of the sounding curves representing the variations of apparent resistivities with current electrode spacing are shown in Figure 3.

The first layer is the topsoil with varying resistivity values from $27.42 \Omega \mathrm{m}$ to $5859.10 \Omega \mathrm{m}$ and the thickness variation from $0.44 \mathrm{~m}$ to $16.09 \mathrm{~m}$. The second layer ${ }^{*}$ TSEPAV MT $;{ }^{2}$ SI. IBRAHIM, ${ }^{1}$ FA. BAYEGUN which comprises of clayey-sand has a layer resistivity ranging from $4.54 \Omega \mathrm{m}$ to $237.50 \Omega \mathrm{m}$ while the thickness of the layer varies from $1.11 \mathrm{~m}$ to $9.40 \mathrm{~m}$. The third layer is the weathered layer which constitutes the aquifer and has resistivity values from $52.69 \Omega \mathrm{m}$ to $22217.8 \Omega \mathrm{m}$ with thickness ranging from $3.89 \mathrm{~m}$ to $1076.6 \mathrm{~m}$. There is the fresh basement rock with resistivity values varying from $22.61 \Omega \mathrm{m}$ to $27987.60 \Omega \mathrm{m}$ and of infinite thickness, just beneath the fractured layer. 
The depth of the first layer varies from $0.440 \mathrm{~m}$ to $2.70 \mathrm{~m}$ while the intermediate layer's depth had a range from $1.55 \mathrm{~m}$ to $17.08 \mathrm{~m}$. The weathered layer shows the deepest depths ranging from $5.44 \mathrm{~m}$ to $1079.5 \mathrm{~m}$. VES 15 proved to be the best location for the possible exploitation of portable groundwater.

The thicknesses and resistivities of the underground strata were used to compute the longitudinal conductance (S) from equation (5) and transverse resistance (R) from equation (7). These parameters were then used to evaluate the aquifer protective capacity and transmissivity of the area respectively. Table 2 shows the longitudinal conductance and aquifer transmissivity as evaluated from the thicknesses and resistivities of the layers using equations (5) and (7) respectively.

The longitudinal conductance $(\mathrm{S})$ values which are the same as the protective capacity $\left(P_{c}\right)$ value of the overburden rock materials of the study area ranged from 0.00039Siemens to 2.052Siemens. The values of the longitudinal conductance are generally low ( $<1.0$ Siemens). This reveals that the overburden rock materials have no significant quantity of impermeable clay overlying strata which demonstrates high infiltration rates of surface contaminants into the aquifer in these areas. This shows that the overburden layers with very low protective capacity are liable to contaminants and are most likely susceptible to soil and groundwater contamination.

The third layer in VES 15 has high longitudinal value $(2.052 \Omega \mathrm{m})$ which implies that the layer has a good aquifer protective capacity which is not prone to contaminants. This layer corresponds to the zone of significant overburden thickness of clayey column, thick enough to protect the aquifer in the area. The transmissivity $(\mathrm{T})$ on the other hand, ranges from $3.96 \times 10^{6} \Omega^{2}$ to $3.34 \times 10^{7} \Omega m^{2}$ in the study area. These transmissivity values are well greater than $400 \Omega \mathrm{m}^{2}$ indicating that the aquifer materials allow the movement of fluid within the aquifer, which may increase the migration of contaminants into groundwater.

Generally therefore, with hindsight of comparative advantage, groundwater exploitation could be achieved from the third layer of VES 2, VES 5, VES 6 , VES 9, VES 10, VES 11, VES 12 and VES 15 with depth ranging from $33.24 \mathrm{~m}$ to $1079.5 \mathrm{~m}$. VES 2, VES 5, VES 6, VES 9, VES 10, VES11 and VES 12 have a

Table 2:- Aquifer parameters estimate from the VES data

\begin{tabular}{|c|c|c|c|c|c|c|c|c|c|c|c|c|c|c|c|c|c|}
\hline \multirow[t]{2}{*}{$\begin{array}{l}\text { VES } \\
\text { No }\end{array}$} & \multirow[t]{2}{*}{ Coordinates } & \multicolumn{3}{|c|}{ Thickness layer (m) } & \multicolumn{3}{|c|}{ Depth (m) } & \multicolumn{3}{|c|}{ Resistivity layer ( $\mathbf{\Omega m})$} & \multicolumn{3}{|c|}{$\begin{array}{l}\text { Longitudinal conductance } \\
\text { (siemens) }\end{array}$} & \multicolumn{4}{|c|}{ Transverse resistance $\left(\Omega \mathrm{m}^{2}\right)$} \\
\hline & & $\mathbf{h}_{1}$ & $\mathbf{h}_{2}$ & $\mathbf{h}_{3}$ & $d_{1}$ & $\mathbf{d}_{2}$ & $d_{3}$ & $\rho_{1}$ & $\rho_{2}$ & $\rho_{3}$ & $\rho_{4}$ & $\mathbf{S}_{1}$ & $\mathbf{S}_{2}$ & $\mathbf{S}_{3}$ & $\mathbf{R}_{1}$ & $\mathbf{R}_{2}$ & $\mathbf{R}_{3}$ \\
\hline 1 & $09^{\circ} 02^{\prime} 51.4^{\prime \prime} \mathrm{N}$ & 1.52 & 14.40 & 7.82 & 1.52 & 15.93 & 23.76 & 84.48 & 46.89 & 1466.2 & 27987.6 & 0.018 & 0.307 & 0.005 & 128.40 & 675.22 & 11465.7 \\
\hline 2 & $\begin{array}{l}006^{\circ} 35,56.3 \text { ”'E } \\
09^{\circ} 02^{\prime} 54.2 \text { "N } \\
006^{\circ} 36^{\prime} 01.3 \text { ” } \mathrm{E}\end{array}$ & 1.87 & 9.39 & 90.94 & 1.87 & 11.26 & 102.2 & 39.45 & 43.04 & 4359.3 & 511.0 & 0.047 & 0.218 & 0.021 & 73.77 & 404.14 & 396407.4 \\
\hline 3 & $\begin{array}{l}0 \overline{9}^{\circ} 02^{\prime} 53.0{ }^{\prime \prime} \mathrm{N} \\
006^{\circ} 36^{\prime} 01.77^{\prime \prime} \mathrm{E}\end{array}$ & 0.98 & 5.32 & 9.39 & 0.98 & 6.30 & 15.70 & 205.40 & 237.5 & 52.69 & 34971.1 & 0.005 & 0.022 & 0.178 & 202.93 & 1263.5 & 494.75 \\
\hline 4 & $\begin{array}{l}09^{\circ} 02^{\prime} 51.6^{\prime \prime} \mathrm{N} \\
006^{\circ} 36^{\prime} 02.5^{\prime \prime} \mathrm{E}\end{array}$ & 1.08 & 4.17 & 19.47 & 1.08 & 5.25 & 24.72 & 88.37 & 40.12 & 1879.8 & 47.35 & 0.012 & 0.104 & 0.010 & 95.43 & 167.30 & 36599.7 \\
\hline 5 & $\begin{array}{l}09^{\circ} 02^{\prime} 50.2^{\prime \prime} \mathrm{N} \\
006^{\circ} 36^{\prime} 03.2^{\prime \prime} \mathrm{E}\end{array}$ & 0.97 & 3.12 & 150.4 & 0.97 & 4.10 & 154.5 & 38.96 & 8.64 & 22217.8 & 1821.3 & 0.025 & 0.361 & 0.007 & 37.86 & 26.95 & 3341557.1 \\
\hline 6 & $\begin{array}{l}09^{\circ} 02^{\prime} 48.7^{\prime \prime} \mathrm{N} \\
006^{\circ} 36^{\prime} 03.8^{\prime \prime} \mathrm{E}\end{array}$ & 1.91 & 14.15 & 17.17 & 1.91 & 16.07 & 33.24 & 34.66 & 112.80 & 434.20 & 4369.8 & 0.055 & 0.125 & 0.039 & 66.24 & 1596.12 & 7455.20 \\
\hline 7 & $\begin{array}{l}09^{\circ} 02^{\prime} 45.5^{\prime \prime} \mathrm{N} \\
006^{\circ} 36^{\prime} 05.4^{\prime \prime} \mathrm{E}\end{array}$ & 2.70 & 5.80 & 22.80 & 2.70 & 8.50 & 31.31 & 4962.5 & 52.51 & 1056.4 & 76.90 & 0.00054 & 0.110 & 0.022 & 13398.75 & 304.55 & 24085.9 \\
\hline 8 & $\begin{array}{l}09^{\circ} 02^{\prime} 47.1{ }^{\prime \prime} \mathrm{N} \\
006^{\circ} 36^{\prime} 04.6^{\prime \prime} \mathrm{E}\end{array}$ & 1.25 & 2.05 & 13.58 & 1.25 & 3.31 & 16.90 & 47.09 & 31.43 & 1234.7 & 246.0 & 0.027 & 0.065 & 0.011 & 58.86 & 64.43 & 16767.22 \\
\hline 9 & $09^{\circ} 02^{\prime} 43.2^{\prime \prime} \mathrm{N}$ & 1.06 & 7.23 & 32.16 & 1.06 & 8.29 & 40.45 & 101.6 & 79.29 & 367.0 & 22.61 & 0.010 & 0.091 & 0.088 & 107.69 & 573.26 & 11802.72 \\
\hline 10 & $\begin{array}{l}\text { nก6.36'05 6"F } \\
09^{\circ} 02 \text { ' } 44.1 \text { "N }\end{array}$ & 2.31 & 5.99 & 37.37 & 2.31 & 8.30 & 45.67 & 229.1 & 5859.1 & 18.00 & 2039.2 & 0.00039 & 0.332 & 0.018 & 13534.52 & 107.82 & 76201.17 \\
\hline 11 & 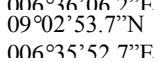 & 1.06 & 9.40 & 59.43 & 1.06 & 10.47 & 69.90 & 35.02 & 22.14 & 867.4 & 566.4 & 0.030 & 0.424 & 0.069 & 37.12 & 208.12 & 51549.50 \\
\hline 12 & $09^{\circ} 02^{\prime} 47.1 ” \mathrm{~N}$ & 0.99 & 16.09 & 56.68 & 0.99 & 17.08 & 73.76 & 40.69 & 30.59 & 1017.10 & 1542.80 & 0.024 & 0.526 & 0.056 & 40.36 & 492.19 & 57649.22 \\
\hline 13 & $\begin{array}{l}006^{\circ} 35,54.0 \text { '” } \\
09^{\circ} 02 \text { '52.8”N } \\
006^{\circ} 35^{\prime} 53.9 \text { ' } \mathrm{E}\end{array}$ & 0.44 & 1.11 & 3.89 & 0.44 & 1.55 & 5.44 & 147.20 & 4.54 & 182.90 & 281.7 & 0.0029 & 0.244 & 0.0212 & 64.76 & 5.04 & 711.48 \\
\hline 14 & $\begin{array}{l}09^{\circ} 02^{\prime} 51.4{ }^{\prime \prime} \mathrm{N} \\
006^{\circ} 35^{\prime} 56.6 \text { ” }\end{array}$ & 1.15 & 5.15 & 17.50 & 1.15 & 6.31 & 23.82 & 27.42 & 18.31 & 167.4 & 785.4 & 0.042 & 0.281 & 0.105 & 31.53 & 94.30 & 2929.5 \\
\hline 15 & $\begin{array}{l}09^{\circ} 02^{\prime} 51.4{ }^{\prime \prime} \mathrm{N} \\
006^{\circ} 35^{\prime} 56.3 \text { ”E }\end{array}$ & 0.72 & 18 & 1076.60 & 0.72 & 2.90 & 1079.5 & 251.7 & 12.70 & 524.4 & 1186.3 & 0.0029 & 0.172 & 2.053 & 181.97 & 27.68 & 564569.04 \\
\hline
\end{tabular}


low longitudinal conductance indicating that these points have a low protective capacity exposing the aquifer in the area to contaminants.

Conclusion: The application of electrical resistivity using the Wenner vertical electrical sounding (VES) has was deployed in the determination of the geoelectrical characteristics of the aquifer and the aquifer parameters. Fifteen (15) VES points were occupied using G41 Geotron Resistivity meter employing the Wenner vertical electrode sounding method with electrode spacing (a) varying from $10 \mathrm{~m}$ to $150 \mathrm{~m}$ while a global positioning system (GPS) tracking device was used to take the coordinates of the VES points. The apparent resistivity data obtained were plotted against electrode separation on a logarithm scale while the $1 \mathrm{xD}$ Interprex interpretation software was used for the interpretation. Four layers comprising the top lateritic soil, silty /clayey, weathered basement and fresh basement rocks were revealed. The resistivity of these layers varied from $4.54 \Omega \mathrm{m}$ to $27987.60 \Omega \mathrm{m}$ while the depth varied from $0.440 \mathrm{~m}$ to $1079.5 \mathrm{~m}$.

The aquifer characteristics in the form of longitudinal conductance and transverse resistance calculated from the interpreted VES results vary from 0.00039Siemens to 2.05 Siemens and $3.96 \times 10^{6} \Omega \mathrm{m}^{2}$ to $3.34 \times 10^{7} \Omega \mathrm{m}^{2}$ respectively. These results showed that some parts of the study area have low protective capacity (<1.0Siemens) which makes the aquifer system in the area to be liable to contaminants. The aquifer overburden protection capacity in VES 2, 5, 6,9,10 and 11 are low which means the aquifer in these locations are susceptible to contaminants while in VES 15 the protective capacity is high and the aquifer is protected. In general, all the locations could be envisaged for groundwater exploration at relatively reasonable depths. However, the consequence of this revelation is that the area is generally unprotected as it allows for infiltration and subsequent contamination of the groundwater and hence good groundwater quality cannot be guaranteed in the area.

\section{REFERENCES}

Ekine, A.S. and G.T. Osobonye, (1996). Surface geoelectric sounding for the determination of aquifer characteristics in parts of Bonny Local Government Area of Rivers State. Nigerian Journal of Physics, 85: 93-97.

El-Qady, G. (2006). Exploration of a geothermal reservoir using geoelectrical resistivity inversion: Case study at Hammam Mousa, Sinai, Egypt. Journal of Geophysics and Engineering, 3: 114121

\footnotetext{
${ }^{* 1}$ TSEPAV MT; * ${ }^{2}$ SI. IBRAHIM, ${ }^{1}$ FA. BAYEGUN
}

Grant, F.S and West, F.G (1965). Interpretation Theory in Applied Geophysics.New York, Mc Graw Hill. 583 pp.

Griffiths, D.H. and Barker, R.D. (1993). Twodimensional resistivity imaging and modelling in areas of complex geology. Journal of Applied Geophysics, 29, 211-226.

Idornigie, A.I., Olorunfemi, M.O. (1992). A Geoelectric mapping of the basement structures

Ismail mohamaden, M.I., (2005). Electric resistivity investigation at Nuweiba Harbour Gulf Aqaba, South Sinal, Egypt. Egyptian Journal Aquatic Research, 31: 57-68.

Kelly, W.E. and M. Stanislav, (1993). Applied Geophysics in Hydrogeological and Engineering

Khalil, M.A. and F.A.S. Monterio, (2009). Influence of degree of saturation in the electric resistivity hydraulic conductivity relationship. Survey in Geophysics, 10.1007/s10712-009-9072-4.

Mbonu, P.D.C., Ebeniro, J.O., Ofoegbu, C.O., and Ekine, A.S. (1991). Parts of Geoelectric sounding for the determination of aquifer characteristics in the Umuahia area of Nigeria. Geophysics, vol.56, pp.284-291.

Nejad, H. T. (2009). Geoelectric Investigation of the Aquifer Characteristics and Groundwater Potential in Behbahan Azad University Farm, Khuzestan Province, Iran. Journal of Applied Sciences 9(20): 3691-3698.

Nwankwo, C.N. and Ehirim, C.N. (2010). Evaluation of aquifer characteristics and groundwater quality using geoelectrical method in Choba,Port Harcourt. Archives of applied science research, 2(2):396-403.

Obaje, N.G, Lar, A., Nzegbuna, A., Moumouni, A., Chaanda, M. and Goki, N. (2006). Geology and Mineral Resources of Nasarawa State; An investor's Guide. Nasara Scientifique, 2, No. 1 of the south central part of the Bida Basin and its hydro-geological implication: Journal of Mining and Geology, NMGS, 28(1), 93-103.

Oladapo M.I. and Akintorinwa O.J.. Hydrogeophysical Study of Ogbese Southwestern, Nigeria. Global Journal of Pure and Applied Science, 13(1), 2007, 55-61 
Omosuyi, G.O., A. Adeyemo, and A.O. Adegoke, (2007). Investigation of groundwater prospect using electromagnetic and geoelectric sounding at Afunbiowo, near Akure, Southwestern Nigeria. Pacific Journal of Science and Technology, 8: 172-182.

Oseji, J.O., Atakpo, E., Okolie, E.C. (2005).

"Geoelectric Investigation of the Aquifer Characteristics and Groundwater Potential in Kwale, Delta State, Nigeria. Journal of Applied Sciences and Environment Management, 9(1): 157 - 160. Practice. Elsevier, Amsterdam, pp: 292.

Sikander, P., A. Bakhsh, M. Arshad and T. Rana, (2010). The use of vertical electric sounding resistivity method for the location of low salinity groundwater for irrigation in Chaj and Rana Doabs. Environment and Earth Science, 60: 11131129.

Vingoe, P. (1972). Electrical Resistivity Surveying. Geophysics Memoranda, 5/72 Sweden.16pp.

Yadav, G.S. (1995). Relating hydraulic and geoelectric parameters of the Jayant aquifer, India. Journal of Hydrology, 167: 23-38.

Zohdy, A.A.., G.P. Eaton, and D.R. Mabey, (1974). Application of Surface Geophysics to Groundwater Investigations. US Geological Survey. 